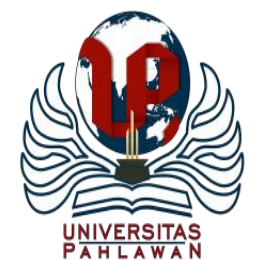

Edukatif: Jurnal Ilmu Pendidikan Volume 1 Nomor 2 Tahun 2019 Halaman 72-79

EDUKATIF: JURNAL ILMU PENDIDIKAN

Research \& Learning in Education

https://edukatif.org/index.php/edukatif/index

\title{
HUBUNGAN FUNGSI AFEKTIF KELUARGA DENGAN PERGAULAN BEBAS REMAJA DI MTS SWASTA NURUL HASANAH TENGGAYUN
}

\author{
Rinda Fithriyana' \\ Program Studi DIII Kebidanan, Universitas Pahlawan Tuanku Tambusai \\ e-mail : rindaup@ gmail.com ${ }^{1}$
}

\begin{abstract}
Abstrak
Remaja merupakan suatu masa dimana seseorang individu mengalami pengalihan dari suatu tahap ketahap berikutnya dan mengalami perubahan baik emosi, tubuh, minat, pola prilaku dan penuh juga dengan masalahmasalah. Masalah yang sering terjadi pada masa remaja adalah pergaulan bebas. Salah satu penyebab pergaulan bebas pada remaja adalah fungsi afektif keluarga. Adapun tujuan dari penelitian ini adalah untuk mengetahui hubungan antar fungsi afektif keluarga terhadap pergaulan bebas pada remaja. Desain penelitian yang digunakan adalah deskriptif analitik dengan pendekatan cross sectional. Penelitian ini dilakukan di MTS Nurul Hasanah Tanggayun dengan jumlah sampel 147 orang. Teknik pengambilan sampel yang digunakan adalah total sampling. Analisa data yang digunakan adalah analisa univariat dan analisa bivariat dengan uji Chi Square. Hasil penelitian diolah menggunakan uji Chi Square dan diperoleh $P$ value $0,006<0.05$ dengan nilai OR 2.826 yang artinya ada hubungan antara fungsi afektif keluarga dengan pergaulan bebas remaja. Hasil penelitian diharapkan dapat menjadi masukan bagi institusi pendidikan agar dapat memperhatikan pergaulan remaja di lingkungan sekolahnya.
\end{abstract}

Kata Kunci: Remaja, Fungsi Afektif Keluarga, Pergaulan Bebas

\begin{abstract}
Adolescence is a time when an individual experiences transfer from one stage to the next and experiences changes in both emotions, body, interests, behavior patterns and is also full of problems. The problem that often occurs in adolescence is promiscuity. One of the causes of promiscuity in adolescents is the affective function of the family. The purpose of this study was to determine the relationship between family affective functions of promiscuity in adolescents. The research design used was descriptive analytic with cross sectional approach. This research was conducted at MTS Nurul Hasanah Tanggayun with a sample of 147 people. The sampling technique used is total sampling. Analysis of the data used is Univariate Analysis and Bivariate Analysis with Chi Square test. The results of the study were processed using the Chi Square test and obtained $P$ value $0.006<0.05$ with a value of $O R 2,826$, which means there is a relationship between the affective function of the family and adolescent free association. The results of the study are expected to be an input for educational institutions to be able to pay attention to adolescent relationships in their school environment.
\end{abstract}

Keywords: Teenagers, Affective Functions of Families, Free Intercourse

@Edukatif: Jurnal Ilmu Pendidikan FIP UPTT 2019

$\triangle$ Corresponding author :

Address : Jl. Tuanku Tambusai No. 23 Bangkinang

Email : rindaup@gmail.com

ISSN 2656-8063 (Media Cetak)

ISSN 2656-8071 (Media Online) 


\section{PENDAHULUAN}

Remaja merupakan suatu masa dimana seseorang individu mengalami peralihan dari satu tahap ketahap berikutnya dan mengalami perubahan baik emosi, tubuh, minat, pola perilaku dan juga penuh dengan masalah-masalah. Perubahan yang paling menonjol adalah perubahan fisik, terutama pada organ-organ seksualnya. Remaja mulai menaruh minat pada lawan jenis dan hal-hal yang berbau seksualitas, terkadang diikuti dengan berbagai macam perilaku yang mengarah pada perilaku seksual (Hurlock, 2013).

\section{Menurut World Health Organitation}

(WHO), remaja adalah penduduk dalam rentang usia 10-19 tahun. Menurut Peraturan Menteri Kesehatan RI Nomor 25 tahun 2014, remaja adalah penduduk dalam rentang usia 10-18 tahun dan menurut Badan Kependudukan dan Keluarga Berencana $(\mathrm{BKKBN})$, rentang usia remaja adalah 10-24 tahun dan belum menikah. Pada tahun 2010 jumlah remaja umur 10-24 tahun sangat besar yaitu sekitar 64 juta jiwa, untuk remaja laki-laki sebanyak 32.164 .436 jiwa $(50,70 \%)$ sedangkan perempuan sebanyak 31.279.012 jiwa $(49,30 \%)$ dari jumlah penduduk Indonesia yaitu sebesar 237,6 juta jiwa (Diana dalam InfoDATIN, 2014).

Remaja dengan rasa keingintahuannya yang sangat besar cenderung melakukan hal-hal yang baru, termasuk dalam kegiatan seksual. Para remaja akan mencari informasi yang terkait dengan hal berbau seksualitas dan akan melakukan berbagai cara untuk memuaskan rasa ingin tahunya tersebut, tanpa memikirkan dampak yang akan terjadi padanya. Hal ini akan membuat remaja akan mudah untuk melakukan tindakan yang menyimpang. Salah satu contoh tindakan menyimpang yang dilakukan remaja adalah banyaknya terjadi perilaku seksualitas (Hurlock, 2013).

Berdasarkan survei SKRRI dalam

BKKBN (2014) menunjukkan pengalaman berpacaran remaja di Indonesia cenderung semakin berani dan lebih terbuka yaitu; 1. Berpegangan tangan, laki-laki 69\% dan perempuan 68,3\%, 2. Berciuman laki-laki 41,2\% dan perempuan 29,3\% 3. Meraba/merangsang, laki-laki $26,5 \%$ dan perempuan 9,1\%. Berdasarkan hasil survei di 33 provinsi di Indonesia pada tahun 2015 menunjukkan adanya peningkatan jumlah remaja yang mengaku pernah berhubungan seks diluar nikah yaitu 62,7\%, 20\% dari 94.270 perempuan yang mengalami hamil di luar nikah juga berasal dari kelompok usia remaja dan $21 \%$ diantaranya pernah melakukan aborsi.

Pergaulan bebas merupakan salah satu bentuk perilaku menyimpang, yang mana "bebas" yang dimaksud adalah melewati batas-batas norma yang ada. Baik di lingkungan maupun dari media massa. Remaja begitu mudah mengikuti ajakan lawan jenis untuk melakukan hubungan seks sebelum menikah dengan alasan suka sama suka dan saling mencintai. Remaja tidak pernah berpikir akibat lanjut yang ditimbulkan. Kebanyakan remaja ingin melakukan hubungan seks karena remaja sekarang dalam menjalani hubungan (berpacaran) yang sangat berani, misalnya berpegangan tangan, saling bersentuhan bibir atau dorongan untuk hasrat seksual (Sarwono, 2011).

Perilaku seks remaja yang tidak bertanggung jawab akan mengakibatkan masalah yang mengganggu kehidupan remaja. Remaja yang sudah mencapai kematangan seksual memiliki dorongan untuk memuaskan kebutuhan seksualnya, tetapi dari sisi kebudayaan dan normanorma sosial yang ada dimasyarakat, melarang pemuasan kebutuhan seksual diluar pernikahan, sehingga remaja harus mampu mengontrol pergaulannya (Hidayat, 2009).

Menurut Purnawan dalam Yuliadi (2010), ada beberapa faktor yang mendorong remaja melakukan seks bebas yaitu dari faktor internal dan eksternal. Faktor internal diantaranya adalah 
tingkat perkembangan seksual, pengetahuan mengenai kesehatan reproduksi dan motivasi. Untuk faktor eksternal adalah keluarga, pergaulan dan media massa. keluarga merupakan tahap awal dari proses perkembangan remaja. Di dalam keluarga hubungan antara orang tua dan anak sangat dipengaruhi oleh persepsi anak dengan sistem pengasuhan dan interpretasinya terhadap motivasi dan hukuman dari orang tua. Hal ini sesuai dengan pendapat Hurlock (dalam Silalahi, 2010) bahwa interaksi dalam keluarga akan berlangsung tidak wajar jika sikap orang tua dipersepsikan tidak baik oleh anak. Oleh karena itu, keluarga memiliki fungsi dan peran yang penting dalam pengasuhan dan pembinaan terhadap perilaku anak.

Keluarga adalah perkumpulan dua atau lebih individu yang terikat oleh hubungan darah, perkawinan atau adopsi, dan tiap-tiap anggota keluarga selalu berinteraksi satu sama lain (Bailon dan Maglaya dalam Setyowati, 2008). Keluarga adalah bagian dari masyarakat yang peranannya sangat penting untuk membentuk kebudayaan yang sehat. Dari keluarga pendidikan kepada individu dimulai dan dari keluarga akan tercipta tatanan masyarakat yang baik, sehingga untuk membangun suatu kebudayaan maka dimulai dari keluarga (Setiadi, 2008).

Menurut Friedman (2010) terdapat 5 fungsi dasar keluarga diantaranya adalah fungsi afektif, fungsi sosialisasi, fungsi reproduksi, fungsi ekonomi, dan fungsi perawatan keluarga. Di dalam keluarga ada beberapa fungsi dan tugas keluarga yang dapat dijalankan oleh anggota keluarga. Berdasarkan beberapa fungsi diatas salah satunya adalah fungsi afektif keluarga.

Fungsi afektif merupakan sumber energi yang menentukan kebahagiaan keluarga dan berhubungan dengan fungsi internal keluarga, perlindungan psikososial serta dukungan terhadap anggota keluarganya, yang merupakan basis kekuatan keluarga. Fungsi afektif keluarga sangat penting bagi perkembangan remaja, karena keluarga mempunyai kewajiban untuk memberikan rasa kasih sayang kepada setiap anggota keluarganya. Keluarga yang harmonis akan terjadi komunikasi antar anggota keluarga dan remaja berkesempatan berkeluh kesah tentang apa yang dirasakannya sehingga remaja akan merasa diperhatikan, dihargai serta dicintai. Jadi apabila fungsi afektif terpenuhi maka remaja akan mampu membatasi pergaulannya karena remaja merasa diperhatikan orang tuanya dan merasa diakui keberadaannya dalam suatu keluarga. Tetapi jika tidak terpenuhinya fungsi afektif keluarga maka remaja akan terjerumus ke dalam hal-hal yang menyimpang seperti pergaulan bebas (Harmoko dalam Rahmadita, E \& Apriyatmoko, R, 2012).

Berdasarkan studi pendahuluan serta data yang didapatkan dari staf bagian kesiswaan dan guru BK MTS Nurul Hasanah Tenggayun yang dilakukan dengan metode wawancara, terdapat beberapa orang siswa yang mempunyai masalah dengan keluarganya, seperti bertengkar dengan orang tua, tidak dipedulikan orang tua dan remaja sering dipukuli oleh orang tuanya. Melalui metode wawancara terhadap 10 orang remaja didapatkan bahwa 8 dari 10 remaja pernah berpacaran dan sering keluar malam untuk berkumpul dengan teman ataupun pacar, 2 dari 10 remaja mengatakan bahwa temannya pernah mengalami meried by accident serta 6 dari 10 remaja juga mengatakan bahwa pada saat mengalami masalah dalam keluarga remaja lebih cenderung cerita atau berbagi dengan teman sebaya, guru Bimbingan Konseling (BK) di sekolah atau memendamnya sendiri dibandingkan cerita atau berbagi dengan anggota keluarga.

Berdasarkan uraian diatas, maka peneliti tertarik untuk melakukan penelitian tentang "Hubungan Antara Fungsi Afektif Keluarga 
Dengan Pergaulan Bebas Remaja Di MTS Nurul Hasanah Tenggayun”.

\section{METODE PENELITIAN}

Jenis penelitian ini adalah kuantitatif. Pendekatan kuantitatif memusatkan perhatian pada gejala-gejala yang mempunyai karakteristik tertentu didalam kehidupan manusia yang dinamakan variabel (Nasir, 2011). Penelitian ini menggunakan desain korelasi dengan pendekatan cross sectional. Menurut Hidayat (2014), cross sectional merupakan rancangan penelitian dengan melakukan pengukuran atau pengamatan pada saat bersamaan atau sekali waktu antara variabel bebas (Fungsi Afektif) dengan variabel terikat (Pergaulan Bebas Remaja).

Penelitian ini dilakukan di MTS Nurul Hasanah Tenggayun pada bulan November tahun 2016. Populasi merupakan seluruh objek penelitian (Hidayat, 2014). Populasi dalam penelitian ini adalah seluruh siswa/siswi kelas VII, VIII dan IX MTS Nurul Hasanah Tenggayun. Jumlah siswa/siswi kelas VII, VIII dan IX sebanyak 147 orang siswa/i.

Sampel adalah objek yang diteliti dan dianggap mewakili seluruh populasi (Notoadmodjo, 2012). Dalam penelitian ini, sampel diambil dengan menggunakan teknik total sampling yaitu mengambil keseluruhan populasi siswa/siswi kelas VII, VIII dan IX yang berjumah sebanyak 147 orang siswa/i.

Instrumen penelitian adalah alat atau fasilitas yang digunakan oleh peneliti dalam mengumpulkan data agar pekerjaannya lebih mudah dan hasilnya lebih baik, lebih lengkap dan lebih sistematis sehingga lebih mudah diolah (Arikunto, 2006). Instrumen yang digunakan dalam penelitian ini adalah angket atau kuesioner yang berupa sejumlah pertanyaan tertulis dengan pertanyaan yang berhubungan dengan masalah yang akan diteliti. Pada fungsi afektif alat yang digunakan untuk mendapatkan fungsi afektif keluarga adalah dengan menggunakan kuesioner dalam bentuk pernyataan.

Analisa yang digunakan adalah analisa univariat dan analisa bivariat. Analisa univariat merupakan analisa yang bertujuan untuk menjelaskan atau mendeskripsikan karakteristik setiap variabel penelitian. Pada umumnya dalam analisis ini hanya menghasilkan distribusi dan persentase dari tiap variabel (Notoadmojo, 2012). Analisis bivariat dilakukan untuk melihat hubungan satu variabel independen dengan satu variabel dependen, bertujuan untuk mengetahui hubungan antara variabel independen utama dengan variabel dependen dengan tanpa mempertimbangkan variabel independen atau faktor risiko lainnya. Analisis bivariat menggunakan uji kai kuadrat (Chi Square).

\section{HASIL DAN PEMBAHASAN PENELITIAN}

Setelah dilakukan penelitian, maka didapatkan hasil sebagai berikut: dari 147 remaja, mayoritas remaja berumur 14-15 tahun sebanyak 109 orang $(74,1 \%)$, mayoritas berjenis kelamin perempuan yaitu sebanyak 83 orang $(56,5 \%)$, mayoritas fungsi afektif keluarga pada tidak terpenuhi yaitu sebanyak 96 orang $(65,3 \%)$, mayoritas pergaulan bebas berada pada kelompok beresiko yaitu sebanyak 82 orang $(55,8 \%)$.

Analisis bivariat dilakukan untuk mengetahui hubungan antara variabel independen (Fungsi Afektif) dan variabel dependen (Pergaulan Bebas) dengan menggunakan uji statistic chi square. Hasil analisis bivariat dapat dilihat pada tabel berikut: 
Tabel 1. Hubungan Fungsi Afektif Keluarga dengan Pergaulan Bebas Remaja di MTS Nurul Hasanah Tenggayun

\begin{tabular}{|c|c|c|c|c|c|c|}
\hline \multirow{3}{*}{$\begin{array}{l}\text { Fungsi } \\
\text { Afektif }\end{array}$} & \multicolumn{4}{|c|}{ Pergaulan Bebas } & \multirow{3}{*}{$\mathrm{N}$} & \multirow{3}{*}{$\begin{array}{c}P \\
\text { Value }\end{array}$} \\
\hline & \multicolumn{2}{|c|}{ Beresiko } & \multicolumn{2}{|c|}{$\begin{array}{c}\text { Tidak } \\
\text { beresiko }\end{array}$} & & \\
\hline & $\mathrm{f}$ & $\%$ & $\mathrm{f}$ & $\%$ & & \\
\hline $\begin{array}{c}\text { Tidak } \\
\text { Terpenuhi }\end{array}$ & 62 & 42.2 & 34 & 23.1 & $\begin{array}{c}96 \\
(100 \%)\end{array}$ & \\
\hline Terpenuhi & 20 & 13.6 & 31 & 21.1 & $\begin{array}{c}51 \\
(100 \%)\end{array}$ & 0.00 \\
\hline Total & 82 & 55.8 & 65 & 44.2 & $\begin{array}{c}147 \\
(100 \%)\end{array}$ & \\
\hline
\end{tabular}

Berdasarkan tabel 1 didapatkan hasil menggunakan uji statistik chi square, diperoleh nilai $P$ velue 0,000 dengan nilai signifikansi $5 \%$ $(<0,05)$ artinya Ho berhasil ditolak atau $\mathrm{Ha}$ diterima dengan nilai OR 2.826. Dari hasil analisis didapatkan bahwa fungsi afektif keluarga yang tidak terpenuhi cenderung beresiko terhadap pergaulan bebas dengan persentase $55,8 \%$ (82 orang) sedangkan fungsi afektif keluarga yang terpenuhi cenderung tidak beresiko terhadap pergaulan bebas dengan persentase 44,2\% (65 orang).

\section{Fungsi Afektif Keluarga}

Berdasarkan hasil penelitian dapat diketahui dari 147 remaja, mayoritas fungsi afektif keluarga pada tidak terpenuhi yaitu sebanyak 96 orang $(65,3 \%)$ dan yang terpenuhi fungsi afektif keluarga yaitu sebanyak 51 orang (34,7\%). Fungsi afektif keluarga berhubungan dengan fungsi internal keluarga, perlindungan psikososial dan dukungan terhadap anggota keluarga, yang merupakan basis dari kekuatan keluarga. Keluarga yang berhasil melaksanakan fungsi afektif yaitu keluarga yang saling mengasuh, saling menghargai atau menghormati, memiliki ikatan bahkan keterpisahan yang mendasari kebahagiaan dari sebuah keluarga (Friedman 2010).

Penelitian ini sejalan dengan penelitian MursaFitri (2015), tentang hubungan fungsi afektif keluarga dengan perilaku kenakalan remaja dengan fungsi afektif keluarga yang tidak terpenuhi yaitu
171 orang $(50,1 \%)$ sedangkan fungsi afektif keluarga terpenuhi yaitu 170 orang $(49,9 \%)$.

Menurut peneliti dapat disimpulkan kebahagian keluarga dapat terpenuhi apabila komponen dalam fungsi afektif dapat dilaksanakan dengan baik oleh keluarga. Sesuai dengan hakikat masa remaja yang merupakan masa peralihan dari masa kanak-kanak ke dewasa yang mengalami perubahan baik fisik maupun psikologis, masa remaja juga rentan terhadap pengaruh dari luar (lingkungan, teman sebaya, teknologi, dll). Jika fungsi afektif keluarga tidak terpenuhi maka seluruh anggota keluarga termasuk remaja tidak dapat mengembangkan konsep diri yang positif (melakukan penyimpangan) karena fungsi afektif merupakan hal yang mendasar dalam membentuk keperibadian, khususnya pada remaja.

\section{Pergaulan Bebas}

Berdasarkan hasil penelitian, dari 147 remaja, mayoritas pergaulan bebas berada pada kelompok Ya mengalami Pergaulan Bebas yaitu sebanyak 82 orang $(55,8 \%)$ dan kelompok yang tidak mengalami pergaulan bebas sebanyak 65 orang $(42,2 \%)$.

Pergaulan bebas adalah suatu hubungan yang meliputi tingkah laku individu yang melewati batas-batas norma yang ada dalam perihal bergaul dengan orang lain dan hal ini merupakan salah satu bentuk perilaku menyimpang (Poedarminto dalam Chusna, 2011).

Penelitian ini sejalan dengan penelitian yang dilakukan oleh Pradyanita (2013) dimana dari hasil penelitian terhadap 120 responden didapatkan 57,50\% mempunyai perilaku negatif dan $42,50 \%$ responden mempunyai perilaku positif yang meliputi kenakalan remaja, dan perilaku penyimpangan sosial. Penyebab yang mempengaruhi remaja melakukan perilaku menyimpang dalam pergaulan bebas karena pengaruh teman sebaya dan pengaruh lingkungan. 
Hasil penelitian ini dapat disimpulkan bahwa perilaku pergaulan bebas dikalangan remaja masih cukup tinggi sehingga sangat diperlukan pengawasan dari sekolah dan peran orang tua untuk memberikan pendidikan kepada remaja. Adapun perilaku menyimpang yang sering dilakukan oleh remaja seperti perkelahian antar pelajar, membolos sekolah, berpacaran, dan tindakan kriminal. Hal ini disebabkan oleh cara dari remaja itu bergaul.

\section{Hubungan Fungsi Afektif Keluarga Dengan} Pergaulan Bebas Remaja Di MTS Swasta Nurul

\section{Hasanah Tenggayun}

Hasil uji statistik Chi square diperoleh nilai $P$ velue 0,005 lebih kecil dari 0,05 , dengan demikian $\mathrm{Ha}$ gagal ditolak yang artinya ada hubungan fungsi afektif keluarga dengan pergaulan bebas remaja di MTS Nurul Hasanah Tenggayun dengan nilai OR 2,8 didapatkan bahwa responden dengan fungsi afektif keluarga yang tidak terpenuhi cenderung beresiko mengalami pergaulan bebas 2,8 kali dibandingkan responden yang fungsi afektif keluarga terpenuhi.

Hasil analisis dari 147 responden yang tidak terpenuhi fungsi afektif keluarga didapatkan pergaulan bebas yang beresiko sebanyak 62 orang $(42,2 \%)$ dan yang tidak beresiko sebanyak 34 orang $(23,1 \%)$ sedangkan yang terpenuhi fungsi afektif keluarga didapatkan pergaulan bebas beresiko sebanyak 20 orang $(13,6 \%)$ dan yang tidak beresiko ada 31 orang $(21,1 \%)$. Jadi remaja yang fungsi afektif keluarga tidak terpenuhi termasuk dalam pergaulan bebas yang beresiko.

Remaja merupakan suatu masa dimana inividu mengalami peralihan dari anak-anak ke dewasa. Pada masa remaja akan terjadi perubahan baik fisik maupun psikologis (Hurlock, 2013). Dalam proses perubahan yang dialami remaja, keluarga merupakan tempat awal dimana remaja melakukan proses sosialisasi dan mengenal segala sesuatu. Didalam keluarga memiliki fungsi afektif yang akan memenuhi kebutuhan psikis yang meliputi saling mengasihi, saling menghargai sehingga akan menyebabkan pembentukan konsep diri pada remaja yang positif. Jika kebutuhan psikis tersebut tidak terpenuhi akan menyebabkan remaja melakukan perilaku menyimpang seperti pergaulan bebas (Friedman, 2010).

Penelitian ini didukung oleh Christiyanti (2010) yang mengatakan bahwa orang tua dengan remaja yang melakukan perilaku kenakalan remaja mempunyai kualitas hubungan komunikasi yang buruk, tidak mempunyai kedekatan dan keterbukaan yang mengakibatkan terjadinya kesenjangan anatara orang tua dan anak.

Penelitian yang dilakukan oleh Sawo (2009) juga mengatakan bahwa keluarga-keluarga di kota besar sulit untuk melaksanakan peranya secara penuh, hal ini disebabkan karena kecenderungan adanya kesibukan orang tua dan kondisi kehidupan kota membatasi pelaksanaan fungsi dan peran.

Dari hasil penelitian diatas peneliti berasumsi bahwa remaja yang fungsi afektif keluarganya tidak terpenuhi cenderung beresiko terhadap pergaulan bebas sedangkan remaja yang fungsi afektif keluarganya terpenuhi cenderung tidak beresiko terhadap pegaulan bebas.

\section{KESIMPULAN}

Dari hasil penelitian yang telah dilakukan tentang hubungan fungsi afektif keluarga dengan pergaulan bebas remaja di MTS Nurul Hasanah Tenggayun dapat disimpulkan sebagai berikut :

1. Berdasarkan hasil penelitian didapatkan 96 remaja mayoritas fungsi afektif keluarga yang tidak terpenuhi

2. Berdasarkan hasil penelitian didapatkan dari 82 remaja mayoritas mengalami pergaulan bebas

3. Hasil uji statistik chi square diperoleh nilai $p$ value 0,005 dan nilai signifikan lebih kecil dari $5 \%(<0,05)$ maka Ho berhasil ditolak atau $\mathrm{Ha}$ 
diterima yang artinya ada hubungan fungsi afektif keluarga dengan pergaulan bebas remaja di MTS Nurul Hasanah Tenggayun 2016.

\section{DAFTAR PUSTAKA}

Ali, M. \& Asrori, M. (2011). Psikologi Remaja (Perkembangan Peserta Didik). Pontianak : Bumi Aksara.

Arikunto, (2006). Prosedur Penelitian Suatu Pendekatan Praktik. Jakarta : Salemba Medika

BKKBN. (2014). Pengelolaan PIK Remaja. Jakarta : BKKBN

Chusna, Y.N. (2011). Peranan Aktivitas "Qalbun Salim” Sebagai Upaya Preventif Pergaulan Bebas Bagi Siswa Smp. Kelas VII - VIII Di Yayasan Lembaga Pendidikan Islam As Sa'adah Benowo Surabaya. http://eprints.uns.ac.id. Di akses tanggal 2 Agustus 2016

Christiyanti, D. (2010). Memahami komunikasi antar pribadi orang tua-anak yang terlibat dalam kenakalan remaja. Diakses tanggal $27 \quad$ Agustus $2016 . \quad$ Dari http://eprints.undip.ac.id

Fatimah,E. (2006). Psikologi Perkembangan (Perkembangan Peserta didik). Bandung : CV. Pustaka Setia

Friedman, M.M. (2010) Buku Ajar Keperawatan Keluarga. Jakarta : Buku Kedokteran EGC

Hidayat, A.A. (2007). Riset Keperawatan dan Teknik Penulisan Ilmiah. Jakarta : Salemba Medika.

Hidayat, A.A (2014). Riset Keperawatan dan Teknik Penulisan Ilmiah. Edisi 2. Jakarta : Salemba Medika.

Hurlock, E.B. (2013). Psikologi Perkembangan, jakarta : Erlangga

Diana, P. (2014). InfoDatin Pusat Data dan Informasi Kementrian Kesehatan RI. http://www.depkes.go.id/resources/downloa d/pusdatin/infodatin/infodatin\%20AIDS. Di peroleh 23 Desember 2015

Kumalasari, I \& Adhiyantoro, I. (2013). Kesehatan Reproduksi Untuk Mahasiswa Kebidanan dan Keperawatan. Jakarta : Salemba Medika

Nasir (2011). Buku Ajar Metodologi Penelitian Kesehatan. Yogyakarta. Nuha Medika

Notoatmodjo, S. (2012). Metodologi Penelitian Kesehatan. Jakarta : Rineka Cipta

Notoatmodjo, S. (2012). Perilaku Kesehatan Masyarakat. Jakarta : Rineka Cipta

Nursalam (2009). Konsep dan Penerapan Metodologi Penelitian Ilmu Keperawatan. Jakarta : Salemba Medika

Potter, \& Perry. (2010). Fundamental Keperawatan. Jakarta: Salemba Medika

Rahmadita, E \& Apriyatmoko, R. (2013). Hubungan Pelaksanaan Peran Dan Fungsi Afektif Keluarga Terhadap Derajat Merokok Pada Perokok Aktif Siswa Laki-Laki (13-15 Tahun) Di SMP 3 Ungaran. Dari http://perpusnwu.web.id.com. Di akses pada tanggal 23 Agustus 2016

Riyanto, A. (2009). Pengolahan dan Analisis Data Kesehatan. Yogyakarta: Nuha Medika

Sarwono, S. W. (2011). Psikologi Remaja. Jakarta: PT. Raja Grafindo Persada

Sawo, I. (2009). Tesis:fungsi keluarga dalam menanggulangi kenakalan remaja

(studi kasus kenakalan remaja di kota madya Jakarta Timur). Diperoleh tanggal 26 Agustus 2016 dari: http://lib.ui.ac.id.com

Setyowati, S \& Murwani, A (2008). Asuhan Keperawatan Keluarga. Yogyakarta :

Setiadi. (2013). Konsep dan Praktik Penulisan Riset Keperawatan. Edisi 2. Yogyakarta : Graha Ilmu

Santrock, J.W. 2002. Psikologi Pendidikan. Jakarta : Prenada Media Group.

Styaningrum, 2014 Kesehatan Reproduksi. Jakarta: TIM

Suryanto \& Susila. (2015). Metodologi Penelitian Cross Sectional. Bosscript

Sulistianingsih, April. (2010). Hubungan Lingkungan pergaulan dan Tingkat 

Tenggayun-Rinda Fithriyana

Pengetahuan Tentang Kesehatan Reproduksi dengan sikap seks bebas Pada

Remaja. Dari https://core.ac.uk.com di akses tanggal 23 Agustus 2016

WHO. (2014). Global Health Observatory Data. http://www.Who.int.gho.hiv/en. di peroleh 23 Agustus 2016 